\title{
Effects of Dehaulming in Potato (Solanum tuberosum) Cultivation: A Review
}

\section{Ashmita Upadhyay*, Saujan Bashyal}

Institute of agriculture and animal science (IAAS), Lamjung Campus, Nepal

${ }^{*}$ Corresponding author

\begin{abstract}
Potato is one of the most important commercial crops worldwide covering 20 million hectares cropping area. Series of cultivation practices are performed in potato cultivation where dehaulming is considered one of the prime-factors that affect the quality and size of tubers. It is also considered as a key factor in production of healthy potato seed in Seed plot technique methods. Dehaulming practice includes the act of detaching and defoliating the vegetative part lying above the ground of potato plant from the underground tuber. Effect of dehaulming is significantly found in the yield of seed tuber, the post-harvest quality of potato tuber and the disease, pest protection aspect of plants. The weight of tuber was found to be $384.20 \mathrm{~g}$ when haulm was cut at 65 days after planting (DAP), then significant increase in weight was found i.e. $533.00 \mathrm{~g}$ when the haulm was cut at $80 \mathrm{DAP}$. And the maximum seed yield was observed when dehaulming was done at 70 DAP i.e. 19.75 t/ha and similar to the non-seed yield. The post-harvest quality of tuber is also significantly improved when dehaulming was performed prior to harvesting. Mainly, the dehaulming practice when performed at 65 DAP was found comparatively safer from infestation and viral disease transmission through the sap sucking pest.
\end{abstract}

Keywords-Potato, Dehaulming, Tuber, Yield, Post harvest.

\section{INTRODUCTION}

Potato is one of most important commercial crops worldwide. With a total cropping area of about 20 million hectares globally, the potato is the fourth most important staple crop after rice, wheat, and maize (Stef de Haan et al,2016). The primary center of origin and diversity of potato crop is found widely prevalent in western region of South America (Hawkes,1990). The first domestication of potato was found to be in southern Peru and northwestern Bolivia between 4000 to $8000 \mathrm{BC}$. The gradual evolution of the diversity of potato in the farmer's hands is foretell to allow its higher adaptation to climate change and the increasing food security on the immoderate agroecology (John and Keen 1986; Zimmer, 2014).

Solanum tuberosum plant is herbaceous in nature which has height upto 0.4-1.4 $\mathrm{m}$ tall and it has prostate to semi erect structure of plant (Spooner and Knapp, 2013). Stem may be hairless to densely hairy with purple green or mottled green in color. It has a single bear terminal leaflet with three to four large ovoid leaves (Spooner and Knapp 2013; Struik,2007).
The flowering pattern usually starts from branches near to the base of the plant and then proceeds upward. The flower remains open for 2 to 4 days, where the receptive stigma and pollen are produced for around 2 days (Plaisted,1980). The storage organ of Solanum tuberosum is tuber that is developed from the swollen underground stem, consisting of several eyes on tuber which are called buds that have potential to sprout and develop into new stem (Hoopes and Plaisted 1987). The tuber formation is much favored in short days. Among the entire cultivation practice dehaulming is considered one of the major practices that determines the qualitative and quantitative character of potato.

Dehaulming is the practice in which aerial parts of a plant are removed 10-15 days before harvesting ("Dehaulming in potato", 2018). Dehaulming can be done after the yellowing of aerial parts because yellowing of the vine indicates the maturity of the potato (Lutaldio et al, 2009). Timing of dehaulming varies according to varieties and in general, the varieties that are not disease resistant are dehaulmed earlier than the disease resistant varieties (Virtanen et al.,2014). 
Generally, there are two methods of dehaulming and they are:

\section{Mechanical methods:}

- Haulm cutting: In this method, aerial parts are cut with sharp objects. Manual cutting takes around 40 man-hours per hectare and hence advanced haulm cutters are developed to increase field efficiency and cutting efficiency (Titiwa et al, 2019).

- Haulm pulling: Haulms are pulled instead of cutting in this method. Manual pulling is a time and labor consuming process. This method is most effective as it does not allow regrowth of foliage (Misener \& Everett 1981; Halderson et al., 1988). There were more fragments of vines in harvested tubers and also tubers' exposure to light was higher in case of haulm pulling method (Halderson et al, 1988).

Chemical method: Through this method, various chemicals are sprayed in foliage, which leads to death of plants. Compared to other methods, it is quite slower ("Seed Potato Dehaulming Methods", 2019). Among various chemicals like sulfuric acid, dinoseb, diquat, endothal, etc., sulfuric acid showed the quickest effect with $42 \%$ of desiccation at day one after application (Haderlie et al, 1989). Compared to Glufosinate-ammonium, diquat had quicker effect on stem and leaf desiccation in 3 and 7 DAT, and after 14 DAT, both had same effect on leaf desiccation but stem desiccation was higher in case of diquat ( Ivany, 2001). Chemical that is applied for haulm cutting also kills weed and thus this method has double advantage ("Vine kill: Method and timing", 2019).

Regrowth of foliage was observed upto $24 \%$ annually when only mechanical methods were used and little regrowth was observed even in chemical methods (Virtanen et al., 2014). So, it is better to use the combination of both mechanical and chemical methods for the most effective haulm destruction and shorter tuber maturation process (Zotarelli et al, 2019).

\section{EFFECTS OF DEHAULMING}

\subsection{Effect of dehaulming on yield}

\subsubsection{Effect on tuber yield:}

The yield and the starch content of tuber is found to have lower in content when the haulm cutting was done before the natural senescence of the plant at an early stage (Struik and Wiersema, 1999). The haulm cutting practice when performed at an early stage where there is low starch content in tuber will directly affect the vitality of tuber to generate new sprouts and roots for consecutive growing seasons. (Sabba et al, 2007). Basically, on a fresh weight basis the tuber growth is almost found to have occurred till 50 days so the tuber per hill parameter is less related to the dehaulming practice. The general tuber per hill number ranges from 12.08 to 15.06 (Beukama and Zaag, 1990). However, the tuber weight per hill increases gradually. According to the research done in Bangladesh, weight of tuber was found to be $384.20 \mathrm{~g}$ when haulm was cut at $65 \mathrm{DAP}$, then significant increase in weight was found i.e. $533.00 \mathrm{~g}$ when the haulm was cut at 80 DAP. However, the result of haulm cutting at 75 and 80 DAP gave statistically similar results i.e. $505.60 \mathrm{~g}$ on an average. So according to the data the yield obtained was 28.02t/ha in haulm cutting at 75 DAP which is almost similar it was 26.02 tons for 70 DAP and the least was for 65 DAP (21.30 t/ha) (Mahumad et al, 2009). So on average a 10-14 days gap between the plant harvest and the dehaulming practice is suitable for the periderm maturity (Waterer, 2007). Also, the 10-14 days period is adequate for skin setting of the tuber which will definitely determine the plant protection tuber quality and seed quality of the yields (Halderson et al, 1988).

However in the northern Europe production condition, prime factor to control the tuber size, haulm cutting is considered as an important practice since tuber growth in long- day condition of north Europe is found to be higher and quicker than normal (Temmerman et al, 2002). Hence haulm cutting is mostly done on strictly immature plants while they may still be flowering which results in unsynchronized timing between the haulm cutting and foliage senescence or maturation of potato tubers (Viraten et al, 2014). In the environment where there is a short growing season, haulm killing is considered as a means for early harvesting, building up the tuber skin before harvesting and obtaining a suitable size of tuber (Struik and Wiersema). 


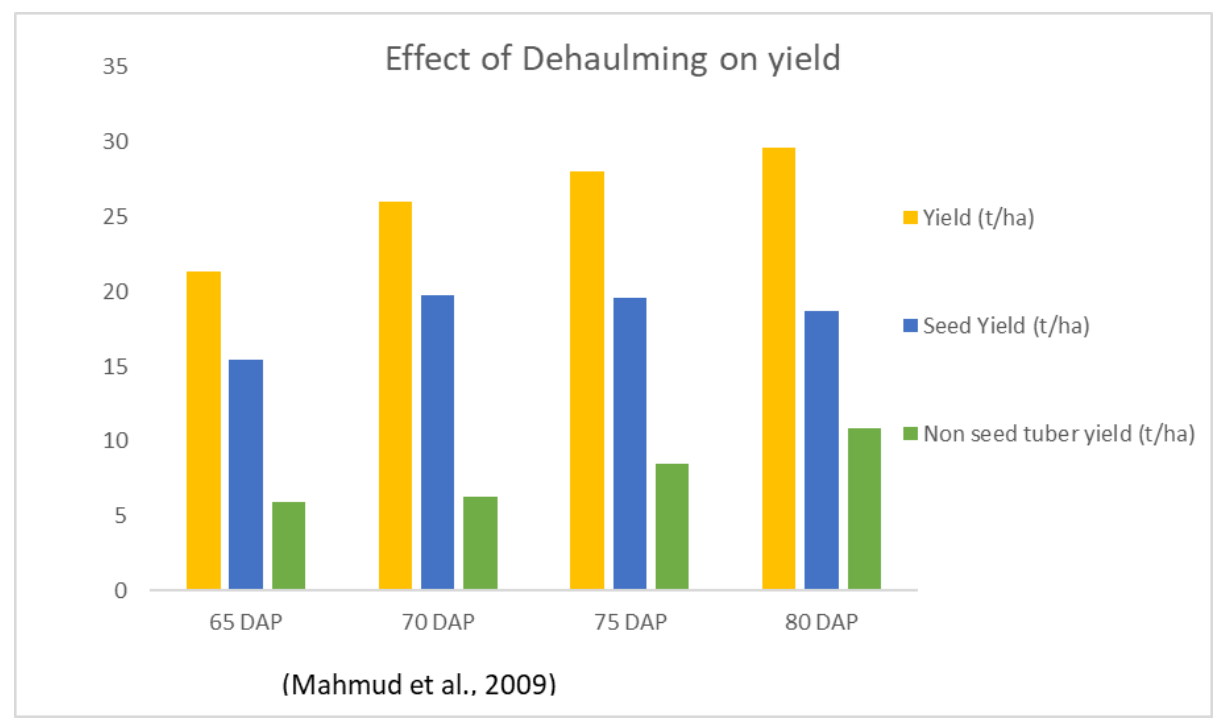

Fig 1: graphical representation of dehaulming effect on yield

\subsubsection{Effect on seed production:}

Quality of seed potato is primarily important in the aspect of yielding a crop and hence the seed production, harvesting (haulming and harvesting) and storage should be carefully carried out (Corrêa et al., 2007). When there is a favorable climatic condition, potatoes usually mature between the interval of 85 to 95 days after planting (Rashid, 1974; Ahmad 1977; Hussain, 1985). Maximum seed yield was observed when haulm cutting was done at 70 DAP i.e. 19.75 t/ha and similar to the non-seed yield. The yield data was statistically similar between haulm cutting at 75 and 80 DAP i.e. $19.56 \mathrm{t} / \mathrm{ha}$ and $18.69 \mathrm{t} / \mathrm{ha}$ simultaneously. However, data as per the research conducted showed the poor seed yield when haulm was cut at 65 DAP i.e. 15.40t/ha. From the data, the maximum yield of non-seed tuber obtained from haulm cutting at 80 DAP was $10.89 \mathrm{t} / \mathrm{ha}$ which is equivalent to $37 \%$. Also the ratio of seed and non-seed was found to be 1:0.318 for haul cutting at $70 \mathrm{DAP}$ and the poor ratio was found for haulm cutting at 80 DAP that is 1:0.583) (Mahumad et al, 2009).

Dehaulming has significant effect on the emergence of seed potato.Those seed potato whose halumed were pulled out three weeks after flowering (75 days after planting) recorded emergence i.e 10.7 days however those seed potatoes whose halum were allowed to mature naturally until the harvest (95 DAP) or were pulled out during the flowering time (50DAP) recorded slow emergence i.e (11.6-12.6days ) (Virtanen, E., et al, 2013). The root and stem bulk production is also influenced by the dehaulming where the physiologically older seed potato produced larger root and stem bulk at 95 days after planting and the seed potato whose haulm has been destroyed at the time of flowering, produced lower root and stem bulk (Virtanen, E., et al, 2013).

\subsection{Effect of dehaulming on post-harvest and qualitative factors}

Dehaulming hardens the potato tubers and increases the shelf life ("A Guide to Potato Production and Post Harvest Management in Kenya", 2013). After dehaulming, tubers are left in the field for 2-3 weeks for the skin to harden and such hardened skin reduces injuries during post harvest handling (Potato Vocabularies Explained, 9 Mar 2020). It generally takes 10-15 days for skin to set (Halderson et al, 1998 ; Virtanen et al, 2014). Respiration rate was minimum in tubers harvested after 90 days and dehaulmed before 10 days of harvesting (Mehta et al, 2003). Weight loss is one of the significant factors that determines the storability of potato tubers. Weight loss was seen minimum in potatoes harvested or lifted 9 days after dehaulming and maximum in potatoes harvested at 0 days after dehaulming (Nipa et al, 2013). However, starch content was found higher in the naturally senesced potato than in mechanically or chemically dehaulmed potato (Virtanen et al, 2014).

Dry matter content is considered a very important characteristic of potatoes when it is grown for industrial purposes. For processing potatoes into chips and French fries, dry matter content should be at least 20\% (Gaur et al, 1999). Higher dry matter is associated with the crispiness 
and lower oil uptake by the fried products (Pope et al,1971; Mehta et al, 2003). Potato with lower dry matter is good for canning purpose (Kumar et al, 2013). There is a significant effect of dehaulming in dry matter content of tubers (Neenan,1965). Mean dry matter increased when dehaulming was delayed from 70 DAP to 80 DAP (Marwaha et al, 2012). Dry matter weight percentage of flesh of potato was found to be $20.55,21.28,22.31,24.60$ and $27.32 \%$ in the potato harvested after 12 days after dehaulming and 12.85, 13.52, $15.52,16.55$ and $18.81 \%$ harvested after 0 days after dehaulming at $0,30,60,90$ and 120 days after storage respectively (Nipa et al, 2013).

Potato should have reducing sugar less than $100 \mathrm{mg} / 100 \mathrm{gm}$ for development of proper color in chips (Marwaha et al, 2005). When the amount of reducing sugar is high, it promotes Millard's reaction and results in darker chips and also in formation of a compound called acrylamide (Kumar et $\mathrm{al}, 2013)$ which is a neurotoxin and a carcinogen (Vainio,2003 ; Bethke et al, 2010). When dehaulming was delayed from 70 to $90 \mathrm{DAP}$, there was significant reduction in the reducing sugar level, with increase in quality of tuber (Marwaha et al, 2012).

Phenolic compounds are generally found in the skin of potatoes and major compounds are phenolic acids and flavonoids (Akyol, Hazal, et al, 2016). Such compounds cause enzymatic discoloration after cutting or peeling (Marwaha et al, 2010). Total phenol content is seen lower when dehaulming is done after 70 DAP and highest when done after 90 DAP (Marwaha et al, 2012).

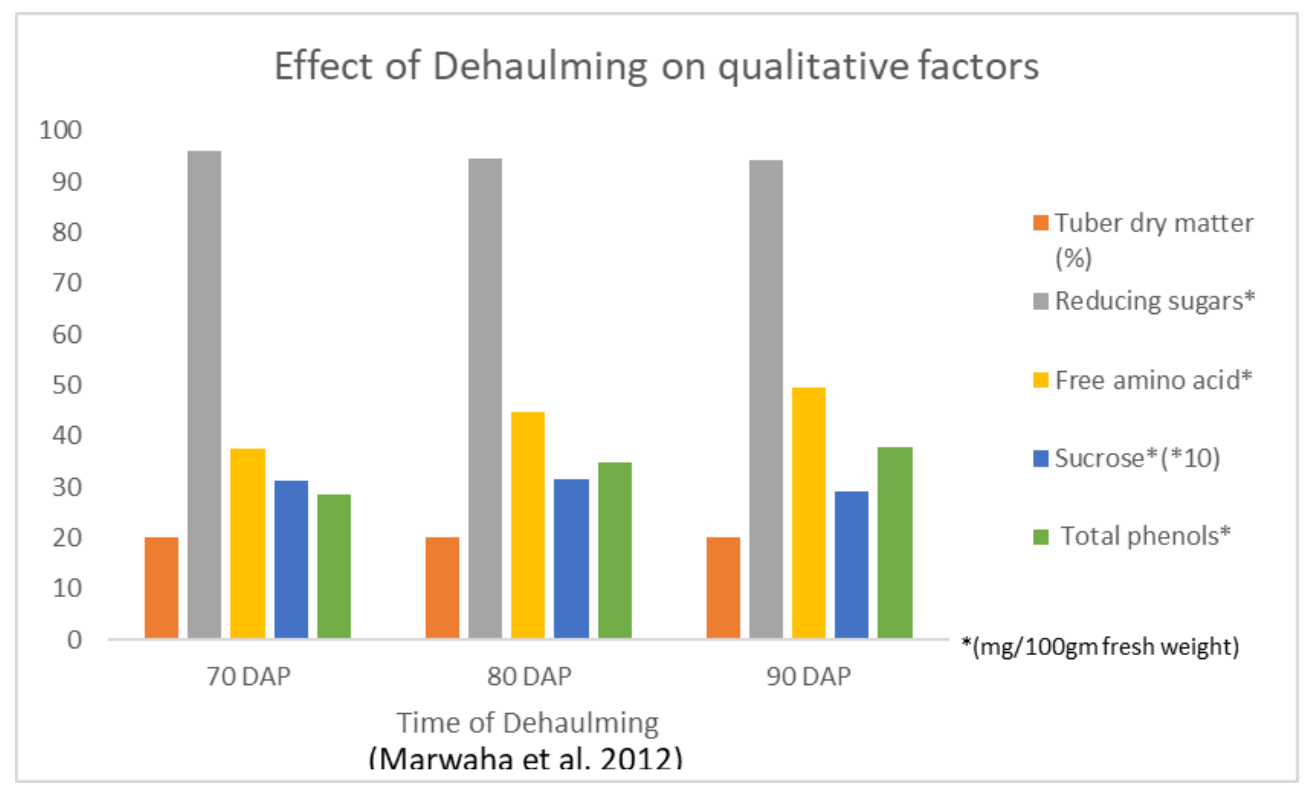

Fig.2: Graphical representation of dehaulming effect on qualitative factors

\subsection{Effect on plant protection:}

Different genera of different soil borne seed borne pathogen and many bacteria and fungus like Rhizoctonia solani (black scurf), Phytophthora infestans (late blight), Phoma foveata (gangrene) and Verticillium dahlie (Verticillium wilt) as well as bacterial diseases are controlled through the practice of haulm killing (Kempenaar \& Struik 2007).

Several researches have been conducted to maximize benefits of haulm killing and minimizing soil transmitted and seed borne disease in seed potato production (Virtanen et al, 2014). However some of the haulm killing methods have been found to increase the plant disease incidence ( Kempenaar et al, 2008; Dijst , 1998). Black scurf is most prevalent in case of mechanical- chemical dehaulming practices (Virtanen et al, 2014). Cutting the stem along with chemical haulm killing aided with the extended period of time between dehaulming and plant harvesting increases the incidence of black scurf disease (Dijst, 1988). Also, Dijst explained that sclerosis formed on the surface of tubers due to the formation of water- insoluble components will ultimately make tubers more prone towards the disease. Immature tubers are more prone towards microbial infection 
and their resistance gradually increases with maturity (Hide and Lap wood, 1992). Pathogens can attack foliage, root systems and tubers, therefore disease and its control can be important throughout the crop cycle. Majorly, the dehaulming practice when performed at $65 \mathrm{DAP}$ was found comparatively safer from infestation and viral disease transmission through the sap sucking pest (Mandal et al, 2020). According to the study conducted in New Alluvial Zone of West Bengal, it was concluded that for quality seed production and less disease pest incidence use of $50 \mathrm{~cm} * 15$ $\mathrm{cm}$ spacing along with haulm cutting at 65 DAP, while planting has to be done in the first week of November (Mandal et al, 2020).

Also, research has found that the incidence of aphids as a vector which carries potato leaf roll virus and the potato tuber moth infestation is controlled by dehaulming and plant part before harvesting. Generally, dehaulming is done in crop immediately when the aphids cross the critical limit of 20 aphids per 100 compound leaves (Awasthi LP, 2017). Also, some research has explained that the viral incidence was $1 \%$ which is regarded to be within permissible limit when the haulm cutting was done by Dec 25 than after the aphid buildup (Awasthi LP, Verma HN, 2017). Thus, the maximum mitigation of crop damage from the leaf roll and severe mosaic was obtained when the seed crops were planted at the end of October and haulm were cut by date when the critical limit of vector is just surpassed (Khurana et al, 1997).

\section{CONCLUSION}

Potato has always been one of the most important foods. It can be consumed as a vegetable or can be processed into various types of products. There are many different cultivation practices and in this article, we discussed dehaulming and its effect on yield, post harvest and qualitative factors and in plant protection. Haulms are destroyed when vines turn yellow indicating the maturity of the plant. Haulm destruction is done by either cutting, pulling or chemical application. Proper dehaulming helps to increase the yield both in terms of tuber size and seed tuber and also minimize injuries during post harvest handling by thickening of skin. Reducing sugar, phenol content, dry matter, free amino acids, etc. determine the quality of potato in industrial level and dehaulming helps to maintain optimum level for these elements. In addition to that, it also plays a significant role in plant protection. Various pathogen carrying pests can be avoided by dehaulming at the right stage that will help to produce disease free tubers.

\section{REFERENCES}

[1] Akyol, Hazal, et al. "Phenolic Compounds in the Potato and Its Byproducts: An Overview." International Journal of Molecular Sciences, vol. 17, no. 6, 2016, p. 835., doi:10.3390/ijms17060835.

[2] Awasthi LP, Verma HN (2017) Current status of viral diseases of potato and their ecofriendly management -A critical review. Virol Res Rev 1: DOI: 10.15761/VRR.1000122

[3] Bethke, P.C., Busse, J.S. Vine-Kill Treatment and Harvest Date have Persistent Effects on Tuber Physiology. Am. J. Pot Res 87, 299-309 (2010). Retrieved from https://doi.org/10.1007/s12230-010-9137-4

[4] Beukema H.P. and V.D. Zaag de. (1990). Crop ecophysiology, In: Introduction to potato production. PUDOC, Wageningen, The Netherlands. pp. 42-60.International Year of the Potato 2008, Retrieved from www.fao.org/potato-2008/en/

[5] Corrêa RM, Pinto JEBP, Faquin V, Pinto CABP, Reis ÉS (2007) The production of seed potatoes by hydroponic methods in Brazil. Fruit Veg Cereal Sci Biotech 3, Special Issue 1: 133-139.

[6] "Dehaulming in potato". (2018, December 08). Retrieved from https://www.agriedu4u.com/2018/11/14/dehaulming-in-potato/

[7] Dijst, G. (1988). Effect of periderm and water-soluble exudates of potato tubers on black scurf formation before and after haulm destruction. Netherlands Journal of Plant Pathology, 94, 247-266.

[8] Gaur PC, Singh SV, Pandey SK, Marwaha RS, Kumar D and Kumar D (1999) Kufri Chipsona-2: A new high dry matter potato variety for chipping. Curr Sci 76: 722-24

[9] "A Guide to Potato Production and Post Harvest Management in Kenya". (2013), Retrieved from www.npck.org/Books/potato\%20production\%20manual.pdf.

[10] Haan, Stef \& Rodriguez, Flor. (2016). Potato Origin and Production. 10.1016/B978-0-12-800002-1.00001-7.

[11] Haderlie, L. C., et al. "Chemical Desiccation of Potato Vines." American Potato Journal, vol. 66, $\quad$ no. 2, 1989, pp. 53-62., doi:10.1007/bf02854424.

[12] Halderson, J. L., Haderlie, L. C., \& Skrobacki, A. (1988). Mechanical vine killing of potatoes. American Potato Journal, $65,415-423$.

[13] Hide G.A, Lapwood D.H, 1992- Disease aspects of potato production, pp. 403-407, - In: HARRIS P.M (ed.) the potato crop: scientific basic for improvement, chapman \& Hale, London

[14] Hussain M.M. (1985). Alu Utpadayanay Pariparshikatar Provab (Influence of environment on potato production). In: Alu Utpadayan, Sangrakkhan O Babohar (Potato production, storage and utilisation). Meer Tochimon Ghani, 85/1, Kakarail, Ramna,Dhaka-2, Bangladesh, pp. 44-50 
[15] Ivany, Jerry A., and J. Brian Sanderson. "Response of Potato (Solanum Tuberosum) Cultivars to Glufosinate-Ammonium and Diquat Used as Desiccants1." Weed Technology, vol. 15, no. 3, 2001, pp. 505-510., doi:10.1614/0890037x(2001)015[0505:ropstc]2.0.co;2.

[16] Kempenaar C \& Struik, P.C (2007) The canon of potato science: haulm killing. Potato Res 50: 341-345. Kerby NW, Dale MFB, Lees AK, Taylor MA \& Bradshaw JE (2005) Breeding and diagnostic developments for better storage of potatoes to meet future industry needs. In Haverkort A.J \& Struik PC (eds) Potato in progress: science meets practice.The Netherlands, Wageningen Academic Publisher: 76-85.

[17] Kempenaar, C., \& Struik, P. C. (2007) Haulm killing. Potato Research, 50, 341-345.

[18] KHURANA, S.M PAUL, editor. "Virus and Virus like Disease of Potato and Their Control." DISEASE OF HORTICULTURAL CROPS - Vegetables, Ornamentals and Mushrooms, Indus Publishing Co, New Delhi, 1999, pp. 82121.

[19] Kumar, Dinesh \& Kumar, Parveen \& Pandey, Subodh Kumar \& Singh, SV. (2013). Processing Potatoes in Sub-Tropical Climates.

[20] Lutaladio, NeBambi, and Oscar Ortiz. Sustainable Potato Production Guidelines for Developing Countries. (2009), Retrieved from www.fao.org/3/a-i1127e.pdf.

[21] Mahmud, Abdullah-AL \& Akhter, Sajeda \& Hossain, M.J. \& BHUIYAN, M. \& Hoque, Md. Azizul. (2009). Effect of dehaulming on yield of seed potatoes. Bangladesh Journal of Agricultural Research. 34. 10.3329/bjar.34i3.3970.

[22] Mandal, M. and Das, S.K. (2020). Effect of intra row spacing, dates of haulm cutting and fertilizer dose on disease free quality seed tuber production of potato (Solanum tuberosum L.) under New Alluvial Zone of West Bengal . Journal of Applied and Natural Science, 12(1): 1 - 8 Retrieved from https://doi.org/10.31018/ jans.v12i1.2204

[23] Marwaha R.S., Pandey SK, Singh SV and Khurana SMP (2005) Processing and nutritional qualities of Indian and exotic potato cultivars as influenced by harvest date, tuber curing, pre-storage holding period, storage and reconditioning under short Days. Adv Hort Sci 19(3): 130-40

[24] Marwaha, R. S., et al. "Potato Processing Scenario in India: Industrial Constraints, Future Projections, Challenges Ahead and Remedies - A Review." Journal of Food Science and Technology, vol. 47, no. 2, 2010, pp. 137-156., doi:10.1007/s13197-010-0026-0.

[25] Mehta, A., \& Kaul, H. (2003). Physiological losses and processing quality of potatoes under ambient temperature storage as influenced by tuber maturity. Advances in Horticultural Science, 17(4), 196-203. Retrieved July 4, 2020, Retrieved from www.jstor.org/stable/42883364

[26] Misener, G. C., \& Everett, C. F. (1981). Vine pulling as a means of top killing potatoes. American Potato Journal, 58, 103-109. http//dx.doi.org/10.1007/BF02854379
[27] Nipa, J \& Roy, Tuhin \& Amin, A.K.M. \& Hasanuzzaman, Md. (2013). Effect of Lifting Time and Tuber Size on Ambient Storage Performance of Potato Derived from True Potato Seed. $\begin{array}{lllll}\text { Int. J. } & \text { Sustain. } & \text { Agric.. } & \text { 5. }\end{array}$ 10.5829/idosi.ijsa.2013.05.01.314.

[28] Neenan, M. (1965). Effect of Premature Haulm Destruction on Yield, Tuber Size and Dry Matter Content of Potatoes. Irish Journal of Agricultural Research, 4(1), 67-80. Retrieved July 4, 2020, Retrieved from www.jstor.org/stable/25555358

[29] "Potato Varieties." The Potato: Varieties - International Year of the Potato 2008, (n.d), www.fao.org/potato2008/en/potato/varieties.html.

[30] "Potato Vocabularies Explained". (9 Mar. 2020), Retrieved from www.npck.org/potato-vocabularies-explained-2/.

[31] RW, Hopes. "Root and Tuber Crop." ROOTS AND TUBER CROP, edited by Plaisted RL and J.E Bradshaw, Scottish Crop Institute, 1980, pp. 99-600.

[32] Sabba, R. P., Bussan, A. J., Michaelis, B. A., Hughes, R., Drilias, M. J., \& Glynn, M. T. (2007). Effect of planting and vine-kill timing on sugars, specific gravity and skin set in processing potato cultivars. American Journal of Potato Research, 84, 205-215. Retrieved from https://dx.doi.org/10.1007/BF02986270

[33] Sandhu, K.S. \& Chinna, G.S. \& Marwaha, Raman \& Pandey, Subodh Kumar \& Kumar, Parveen \& Singh, R.K.. (2012). Effect of staggered planting and dehaulming schedule on yield and processing quality of potato cultivars in Punjab. Potato Journal. 39. 39-47.

[34] "Seed Potato Dehaulming Methods". (2019), Retrieved from www.npck.org/seed-potato-dehaulming-methods/

[35] Spooner, David \& Ghislain, Marc \& Simon, Reinhard \& Jansky, Shelley \& Gavrilenko, Tatjana. (2014). Systematics, Diversity, Genetics, and Evolution of Wild and Cultivated Potatoes. The Botanical Review. 80. 10.1007/s12229-0149146-y.

[36] Struik, P. C., \& Wiersema, S. G. (1999). Seed Potato Technology. The Netherlands: Wageningen Pers.

[37] Temmerman, L., Wolf, J., Colls, J., Bindi, M., Fangmeier, A., Finnan, J., Ojanperä, K., \& Pleijel, H. (2002). Effect of climatic conditions on tuber yield (Solanum tuberosum L.) in the European "CHIP" experiments. European Journal of Agronomy, 17, 234-355. Retrieved from https://dx.doi.org/10.1016/S1161-0301(02)00064-3

[38] Titiwa, K P, et al. Development of Potato (Solanum Tuberosum L.) Haulm Cutter. IOP Conference Series: Earth and Environmental Science, vol. 301, 2019, p. 012009., doi:10.1088/1755-1315/301/1/012009.

[39] Vashisth, K.S., AK Verma, IP Chaube and BB Nagaich. 1981. Comparative degenerative effects of viral and MLO-Diseases during Autumn and Spring seasons of Indian potato varieties in Punjab. Seeds and Farms 11: 25-28.

[40] "Vine Kill: Method and Timing." Potato Country, (3 Sept. 2019), Retrieved from 
www.potatocountry.com/2019/09/03/vine-kill-method-andtiming/.

[41] Virtanen, E., et al. "Effects of Production History and Gibberellic Acid on Seed Potatoes." Journal of Agricultural Science, vol. 5, no. 12, 2013, doi:10.5539/jas.v5n12p145.

[42] . "Effects of Haulm Killing on Seed Potato Quality." Journal of Agricultural Science, vol. 6, no. 3, (2014), doi:10.5539/jas.v6n3p168.

[43] Waterer, D. (2007). Vine desiccation characteristics and influence of time and method of top kill on yields and quality of four cultivars of potato (Solanum tuberosum L.). Canadian Journal of Plant Science, 87, 129-135. Retrieved from https://dx.doi.org/10.4141/P06-074

[44] Lincoln Zotarelli, Steven Sargent, et al. Potato Vine Killing or Desiccation. University of Florida IFAS Extension, Feb. 2019, edis.ifas.ufl.edu/hs181. 